\title{
COMPARATIVE RESEARCH ON REALIZATION OF AGROTEHNICAL INDICES BY SEEDLING PLANTING MACHINES WITH BUCKET DISPENSERS
}

\author{
Paul Mitrache ${ }^{1}$, Ion Saracin ${ }^{1}$, Radu Ciuperca ${ }^{2}$ \\ ${ }^{1}$ University of Craiova, Romania; ${ }^{2}$ National Institute of Research-Development for Machines and \\ Installations Designed to Agriculture and Food Industry, Romania \\ paulmariusmitrache@gmail.com, ion_saracin@yahoo.com,ciupercaradu@yahoo.com
}

\begin{abstract}
In the paper there are some comparative researches on planting machines with nutrient bale, equipped with rotary bucket dispensers, which are the most used models due to the fact that they are the most efficient and the most spread at the present time for planting seedlings. We will limit ourselves to the analysis of the representative types, from a constructive and functional point of view, namely, the machines equipped with articulated bucket dispensers, their vertical rotation, respectively those with fixed bucket dispensers, with rotation in horizontal plane. Some achievements are being made worldwide in the field of planting machinery, especially those equipped with rotary disc and bucket dispensers. In addition to their constructive and functional description, there is an analysis of the advantages and disadvantages of each type achieved, seen from the perspective of complying with the seedling planting technology, on the one hand, and functionality, maintenance and economic aspects, on the other hand. Recommendations of agro-technical and technological requirements are presented for planting seedlings, such as: rows planted to be straight, deviations from the permitted row axis are max. $5 \%$ within $\pm 20 \mathrm{~mm}$; the planting depth can be achieved within $30-150 \mathrm{~mm}$; the position of the planting seedlings is as close as possible to the vertical; the percentage of seedlings improperly planted (inclined more than 300 to the vertical, ground covered, left on the ground or damaged) is less than $5 \%$. The tested equipments are presented, their characteristics, advantages and disadvantages, the conditions under which the experiments were carried out will also be presented, as well as the equipment used to perform the experiments. The results obtained constitute the basis for comparative analysis and summaries, the constructive types analysed are identified, specifying for each of how they meet, or not, the agri-technical requirements imposed on the work of planting seedlings, depending on the advantages and disadvantages presented for each type are analysed. Based on the analysis carried out, conclusions on the results are obtained and recommendations on optimal solutions are presented.
\end{abstract}

Keywords: planted seedlings, buckets, dispensers.

\section{Introduction}

Manufacturers of technical equipment for planting seedlings produced in the nutritive plant pot have tried to adopt the most varied technical solutions [1].

Machinery for planting seedlings, fitted with bucket dispensers, developed by specialized producers, has evolved over time in various printer sizes and designs, for each new model an attempt is made to improve the building solutions, so as to eliminate the disadvantages of previous models in order to achieve increased working capacity under high quality parametric conditions.In 1981, W. Stewart BootsJay C. Altmanpatented a seedlingplantingmachinethathas a bucketplantingsystem, rotatinghorizontally [2].

The usersitting on thechairmanually puts theplants, takenfromthestoragetray in thecups. Threechaingearsand a taped gear transmission transmit themovementfromthedisplacementwheelto a rotatingsystem in a horizontal plane towhicht its cups are attached.

In 1992, Howard N. Poll obtained a patent for a planting machine with a rotating cup. The system of planting rotary cup has been enhanced by the fact that the number of cups is increased from 4 to 6 and the shape, size and pattern of release modified such that the seedlings of the plants to be protected do not cause degradation of the plant [3].

Improvement in building cups from the previous is that they have round shapes, without corners that can hit the plants, they are deeper for larger plants, protect the leaves and opening of the two halves to open only the bottom facilitates the fall of the plant seedling and less likely to cling. Cups were brought closer to the conveying tube furrow to make a transfer quickly and safely. The tube through which the plant is attached to the ground moves with it and places the plant. A new element not found in the previous car is a disk to break the soil crust before the furrow opener.

In 1998 Howard Kolk, Robert Kolk, the Netherlands, brought improvements to the bucket type rotary machine, previous development. To place the plants in the trench the machine works in a 
predetermined distance range set by the operator in the control electronics. For this electronic system a variable speed electric motor is used to control the speed of the system, but it can control the planting bucket and the speed of the tractor [4].

An automatic planting machine was developed by the Ferrari company for very large farms, where land is pooled. This machine was built for vegetable seedling trays stored in different sizes and it needs only one operator to feed the drive tray. Seedlings are extracted automatically by means of a cylindrical piston-based system combined with the fingers and lifts, it moves the seedling tray by the pressure coming out of the bottom of the piston. Planting distributor rotates clockwise and is coordinated by an electronic STOP \& GO [5].

An automatic machine for transplanting potted tomato seedlings was designed, based on the analysis of physical characteristics of the main varieties of tomato seedlings. The machine is composed of a horizontal and vertical seedling supply mechanism, a picking mechanism composed with a gear-rod component, a planting part featured with an eccentric-disk parallelogram duckbilled mechanism, and a control system. The control system includes position sensors, stepper motor, variable-frequency motor and program controller. The result demonstrated that the machine was feasible to transplant the potted tomato seedlings efficiently [6].

Problems need to be solved, when a seedling planting tine draws an approximately circular-arc rise and fall locus line by high-speed rotary drive in a double crank mechanism state, separates matlike seedling nursery beds fed from a seedling tank, plants seedlings in the soil surface and frictional resistance in separating the nursery bed parts is high for the planting, seedling roots, seedling body parts. The seedling planting time of the seedling planting machine has a constitution that forked parallel needle parts are formed at the tip part, each of the needle parts is equipped with a flat needle body surface, a needle angle edge along the outside edge of the needle body surface is successively inclined inside from the needle tip side to a base part [7].

In view of the current large labour intensity of seedling transplanting, low efficiency, unable to complete the task of transplanting on time and other issues, a kind of automatic seedling transplanting machine is designed based on motion controller. The test proves that the seedling transplanting machine can realize the automatic transplanting process, improve transplanting efficiency, and reduce the cost of transplanting, it has a certain practical significance [8].

\section{Materials andmethods}

Recommended agro-technical and technological requirements for planting seedlings:

- rows planted to be straight, deviations from the permitted row axis are max. $5 \%$ within $\pm 20 \mathrm{~mm}$;

- the row spacing is adjustable, preferably continuous, starting at min. $300 \mathrm{~mm}$, to allow maintenance and harvesting operations to be mechanized;

- the distance between the plants can be adjusted, either continuously or in steps of $50 \mathrm{~mm}$, within 100-1200 mm;

- the planting depth can be achieved within 30-150 mm;

- the position of the planting seedlings is as close as possible to the vertical;

- the percentage of seedlings improperly planted (inclined more than $30^{\circ}$ to the vertical, ground covered, left on the ground or damaged) is less than $5 \%$, [9-12].

Description of the tested machines of two variants is as following.

Variant 1. The planting machine with a vertical spreader with articulated buckets [13], Fig. 1, consists mainly of: machine frame (1), drive wheel (2), transmission (3), box support (5) and two planting sections made up of the section (6), depth adjustment wheels (4), swath wheels (7), final drive (8), rotary distributors with buckets (9), task wheels (10), seat.

In the transmission, Fig. 1, by changing some sprocket chains, several gear ratios can be obtained, which in conjunction with the number of buckets on the distributor result in a large number of different distances between the seedlings at a time, approx. 46 distances. 


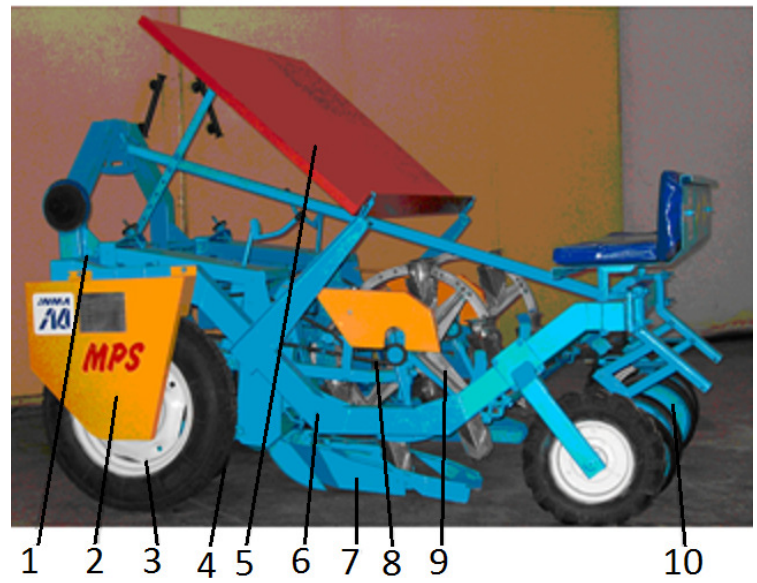

Fig. 1. Machine of planting vegetable seedlings

Variant 2. The planting machine equipped with horizontal distributor and fixed buckets [14]. The planting unit with horizontal dispenser and fixed buckets is of the type shown in Fig. 2 and consists of a rotary system (1), the comprising a rotor on which the buckets (2) are driven by a group of bevel gears, the bucket opening cam (3), a guide tube to the windrow (4), the plant laying leg in the ditch (5) and the ditch opening furrow (6).
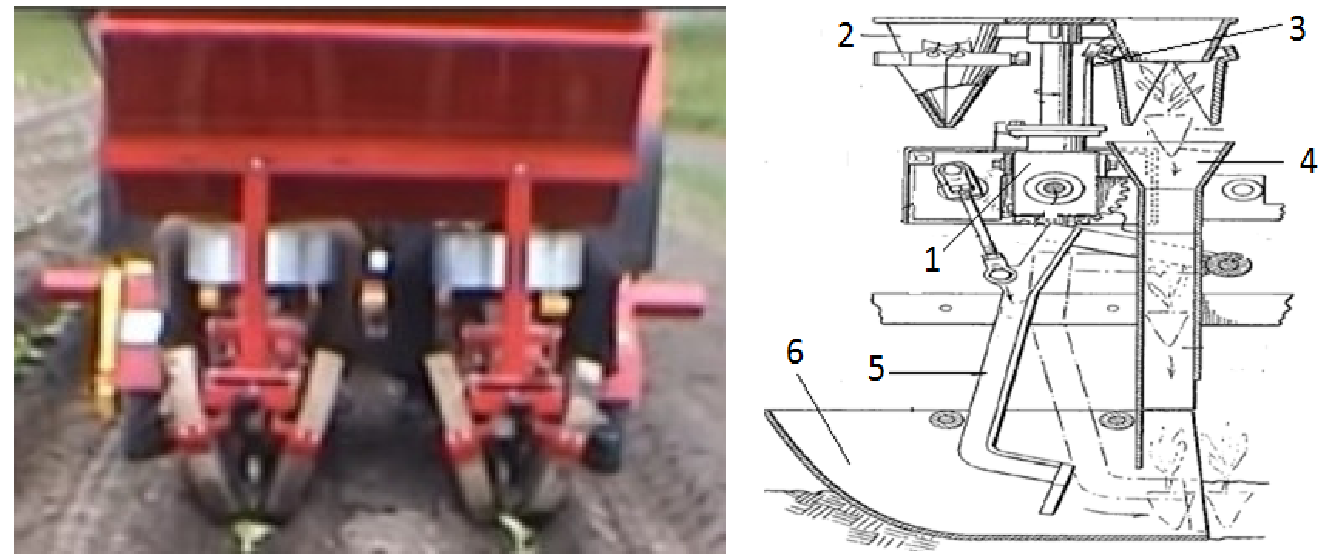

Fig. 2. Planter with horizontal distributor and fixed buckets: 1 - rotary system; 2 - buckets; 3 - bucket opening cam; 4 - swath guiding tube; 5 - plant placement leg; 6 - furrow

Planting unit kinematics. Figures 3 and 4 show the planting unit kinematics transmission diagrams for the two planting unit variants.

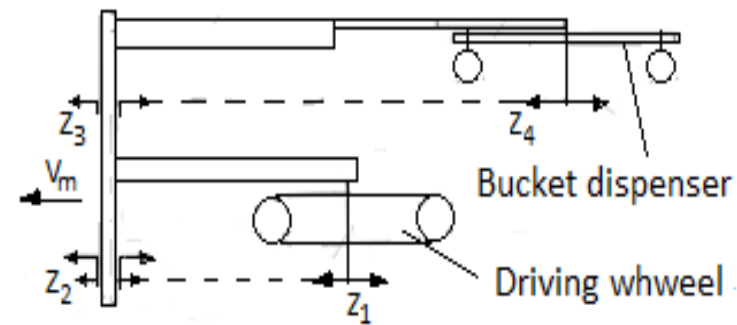

Fig. 3. Planter gear drive kinematic diagram, Variant 1

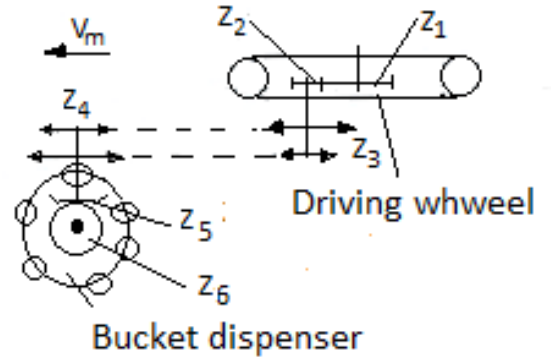

Fig. 4. Planter gear drive kinematic diagram, Variant 2

The rotational frequency of the spinner with buckets is determined with the relationship (1), Variant 1and relationship (2), Variant 2.

$$
n_{2}=n_{1} \cdot i=n_{1} \cdot i_{1} \cdot i_{2}=n_{1} \cdot \frac{z_{1}}{z_{2}} \cdot \frac{z_{3}}{z_{4}}=\frac{30 \cdot v_{m}}{\pi \cdot R_{a}} \cdot \frac{z_{1}}{z_{2}} \cdot \frac{z_{3}}{z_{4}},
$$




$$
n_{2}=n_{1} \cdot i=n_{1} \cdot i_{1} \cdot i_{2} \cdot i_{3}=n_{1} \cdot \frac{z_{1}}{z_{2}} \cdot \frac{z_{3}}{z_{4}} \cdot \frac{z_{5}}{z_{6}}=\frac{30 \cdot v_{m}}{\pi \cdot R_{a}} \cdot \frac{z_{1}}{z_{2}} \cdot \frac{z_{3}}{z_{4}} \cdot \frac{z_{5}}{z_{6}},
$$

where $R_{a}$-driving wheel radius, $\mathrm{m}$;

$n_{1}-$ rotative speed of the driving wheel, $\mathrm{s}^{-1}$;

$n_{2}-$ rotative speed of the bucket distributor, $\mathrm{s}^{-1}$;

$v_{m}-$ drive speed of the unit in, $\mathrm{m} \cdot \mathrm{s}^{-1}$.

Tests under the conditions of exploitation of the two types of seedlings were carried out in the aggregate with a $45 \mathrm{hp}$ vegetable tractor, under the same conditions, for tomatoesandcabbagecropswith seedlings in nutrient pots.

For plantingtomatoes, the spacebetweenrows, is $80 \mathrm{~cm}$, and for cabbage $70 \mathrm{~cm}$, thesedistances are mostusedwhenplantingthesetwocrops. The field on whichplanting took place has been well processed, reduced and leveled.

The size of the propagating material and its degree of growth are given in Table 1.

Materials for planting and their characteristics

Table1

\begin{tabular}{|c|c|c|c|c|}
\hline \multirow[b]{2}{*}{ Seedlings } & \multirow{2}{*}{$\begin{array}{c}\text { Dimensions of } \\
\text { thenutrient pot, } \\
\text { mm }\end{array}$} & \multicolumn{3}{|c|}{ Seedling stage of growth } \\
\hline & & Height, mm & $\begin{array}{l}\text { Diameter of } \\
\text { stem, mm }\end{array}$ & $\begin{array}{c}\text { Number of } \\
\text { leaves }\end{array}$ \\
\hline Tomatoes & $40 \times 40 \times 40$ & $150-260$ & $3-5$ & 4-7 \\
\hline Cabbage & $40 \times 40 \times 40$ & $130-160$ & $2.5-3.0$ & $2-4$ \\
\hline
\end{tabular}

\section{Results and discussion}

The results of the experimentscarried out with the twotypes of plantingmachines are given in Table 2, 3 and 4 .

Experiments have shown that both variants allow the rows pacing and the plantspacing to be adjusted in line with the conditionslaid down in the existingtechnicalstandards and the cultivationtechnologiesused.

In the experiments five measurements were carried out for the distance between the plants one at a time, the planting depth and the deflection of the planted seedbed from the vertical position has been visually assessed, the degree of injury of the plants and the plants left on the ground surface, these parameters are the most important in the work. Using the determined values, the indices of appreciation have been calculated according to the relationships $(3,4,5)$.

Absolute average, $V_{m a}$, calculated with relation (3):

$$
V_{m a}=\frac{\sum_{1}^{n} v_{i}}{n}
$$

where $V_{i}$ - measured value, $\mathrm{cm}$;

$n$ - number of measurements taken.

The root mean square deviation, $\sigma_{a}$ calculated with the relationship (4):

$$
\sigma_{a}= \pm \sqrt{\frac{\sum_{i=1}^{n}\left(v_{i}-v_{m a}\right)^{2}}{n-1}}
$$

The variation index $V_{a}$ will be calculated with the relationship (5):

$$
V_{a}=\frac{\sigma_{a}}{v_{m a}} \times 100 \%,
$$


Damaged plants, deviations to vertical, plants inappropriately seeded

\begin{tabular}{|c|c|c|c|c|c|c|c|c|}
\hline \multirow{2}{*}{$\begin{array}{c}\text { Number } \\
\text { of } \\
\text { seedlings } \\
\text { planted }\end{array}$} & \multicolumn{2}{|c|}{$\underset{\%}{\operatorname{Damaged}} \underset{ }{\mathrm{s}}$} & \multicolumn{2}{|c|}{$\begin{array}{l}\text { Deviations to } \\
\text { verticalposition } \\
\left(>30^{\circ}\right), \%\end{array}$} & \multicolumn{2}{|c|}{$\begin{array}{l}\text { Plants left on } \\
\text { the soil, \% }\end{array}$} & \multicolumn{2}{|c|}{ Total, \% } \\
\hline & $\begin{array}{c}\text { Variant } \\
1\end{array}$ & $\begin{array}{c}\text { Variant } \\
2\end{array}$ & $\begin{array}{c}\text { Variant } \\
1\end{array}$ & $\begin{array}{l}\text { Variant } \\
2\end{array}$ & $\begin{array}{c}\text { Variant } \\
1\end{array}$ & $\begin{array}{l}\text { Variant } \\
2\end{array}$ & $\begin{array}{c}\text { Variant } \\
1\end{array}$ & $\begin{array}{c}\text { Variant } \\
2\end{array}$ \\
\hline $\begin{array}{c}\text { Tomatoes } \\
225\end{array}$ & 1.78 & 2.22 & 1.34 & 2.67 & 1.34 & 0.00 & 4.46 & 4.89 \\
\hline $\begin{array}{c}\text { Cabbage } \\
225\end{array}$ & 1.33 & 2.22 & 0.00 & 2.22 & 1.7 & 0.00 & 3.03 & 4.44 \\
\hline
\end{tabular}

Table 3

Distance between rows andbetween plants in a row, planting depth - Tomatoes

\begin{tabular}{|c|c|c|c|c|c|c|}
\hline \multirow{3}{*}{$\begin{array}{c}\text { No.ofthe } \\
\text { measurement }\end{array}$} & \multicolumn{3}{|c|}{ Between plants in a row, $\mathrm{cm}$} & \multicolumn{3}{|c|}{ Plantingdepth, cm } \\
\hline & \multirow{2}{*}{$\begin{array}{l}\text { Adjusted } \\
\text { value, cm }\end{array}$} & \multicolumn{2}{|c|}{ Measured values } & \multirow{2}{*}{$\begin{array}{l}\text { Adjusted } \\
\text { value, } \mathrm{cm}\end{array}$} & \multicolumn{2}{|c|}{ Measured values } \\
\hline & & $\begin{array}{c}\text { Variant } \\
1\end{array}$ & $\begin{array}{c}\text { Variant } \\
2\end{array}$ & & Variant 1 & $\begin{array}{l}\text { Variant } \\
2\end{array}$ \\
\hline 1 & \multirow{8}{*}{35} & 35.4 & 35.5 & \multirow{8}{*}{6} & 6.2 & 6.3 \\
\hline 2 & & 35.5 & 36.8 & & 6.0 & 5.8 \\
\hline 3 & & 35.3 & 35.0 & & 6.2 & 6.6 \\
\hline 4 & & 35.5 & 36.5 & & 6.3 & 6.3 \\
\hline 5 & & 35.2 & 37.2 & & 5.8 & 7.2 \\
\hline $\begin{array}{c}\text { Absolute average } \\
V_{m a}, \mathrm{~cm}\end{array}$ & & 35.38 & 36,20 & & 6.10 & 6.44 \\
\hline $\begin{array}{l}\text { Root mean square } \\
\text { deviation } \sigma_{a}, \mathrm{~cm}\end{array}$ & & 0.12 & 0.92 & & 0.2 & 0.55 \\
\hline Variation index $V_{a}, \%$ & & 0.34 & 2.54 & & 3.30 & 8.60 \\
\hline
\end{tabular}

Table 4

Distance between rows and between plants in a row, planting depth - Cabbage

\begin{tabular}{|c|c|c|c|c|c|c|}
\hline \multirow{3}{*}{$\begin{array}{c}\text { No.ofthe } \\
\text { measurement }\end{array}$} & \multicolumn{3}{|c|}{ Between plants in a row, $\mathrm{cm}$} & \multicolumn{3}{|c|}{ Plantingdepth, cm } \\
\hline & \multirow{2}{*}{$\begin{array}{l}\text { Adjusted } \\
\text { value, cm }\end{array}$} & \multicolumn{2}{|c|}{ Measured values } & \multirow{2}{*}{$\begin{array}{l}\text { Adjusted } \\
\text { value, cm }\end{array}$} & \multicolumn{2}{|c|}{ Measured values } \\
\hline & & Variant1 & Variant 2 & & Variant 1 & Variant 2 \\
\hline 1 & & 30.4 & 30.8 & & 6.3 & 6.8 \\
\hline 2 & & 30.3 & 31.3 & & 6.2 & 6.3 \\
\hline 3 & 30 & 31.0 & 31.3 & 6 & 5.9 & 6.9 \\
\hline 4 & & 30.5 & 30.7 & & 6.3 & 7.3 \\
\hline 5 & & 30.4 & 30.2 & & 6.3 & 7.0 \\
\hline $\begin{array}{c}\text { Absolute average } \\
V_{m a}, \mathrm{~cm}\end{array}$ & & 30.52 & 30.86 & & 6.2 & 6.86 \\
\hline $\begin{array}{l}\text { Root mean square } \\
\text { deviation } \sigma_{a}, \mathrm{~cm}\end{array}$ & & 0.27 & 0.52 & & 0.054 & 0.37 \\
\hline Variation index $V_{a}, \%$ & & 0.90 & 1.68 & & 0.90 & 5.4 \\
\hline
\end{tabular}

As a general conclusion, it can be said that planting machines equipped with a vertical dispenser with articulated buckets achieve qualitative working indices higher than those equipped with a horizontal dispenser and fixed buckets. This is due to the fact that the planting unit from the Variant 2 has three transmissions in the component, and therefore, the theoretical return of motion transmission 
is less accurate than foe the Variant 1, which has two transmissions. Deviations may also occur due to the inherent phenomenon of driving wheel slippage in this type of machine.

The planting machine in Variant 1 is equipped with a parallelogram, which ensures a level position at all times that means the maintenance of a constant planting depth.

\section{Conclusions}

1. The percentage of seedlings improperly planted (inclined more than $30^{\circ}$ to the vertical, ground covered, left on the ground or damaged) is less than $5 \%$;

2. The deviations achieved from the distance between the plants per row under control are insignificant for both variants, with the Variant 2 being higher, particularly for the variation index of the measured parameters, i.e. $2.54 \%$ and $1.68 \%$ for the two cultures, compared with $3.34 \%$ and $0.9 \%$ for Variant 1.

3. The deviations achieved from the adjusted planting depth at a time are insignificant for both variants, with Variant 2 having higher values, particularly for the variation index of the measured parameters, i.e. $8.60 \%$ and $5.4 \%$ for both crops, compared with $3.30 \%$ and $0.9 \%$ for Variant 1.

\section{References}

[1] Mitrache P.M, Saracin I., Ciuperca R. Comparative study on seedlings planting machines with cups dispensers ISB-INMA-TEH 2019, International Symposium, 2019, Bucharest, Romania, pp. 796-803.

[2] Boots W.S., Altman J.C. Seedling planting machine with rotary cups, 1981, patent US 290373.

[3] Poll H., Seedling planting machine with rotary cups, 1992, patent US 5159887.

[4] Kolk H., Kolk R., et.al, Seedling planting machine with rotary cups, 1998, patent US5823126.

[5] FUTURA TWIN AUTOMATED Transplanter [online][11.02.2020] Availabile at: https://ferraricostruzioni.com/en/tray-transplanters/41-futura-twin-automated-transplanter.html.

[6] Xin J., Kaixuan Z., Jiangtao J. Design and Experiment of Automatic Transplanting Device for Potted Tomato Seedlings, Proceedings of the Institution of Mechanical Engineers, Part C: Journal of Mechanical Engineering Science, March 15, 2018. pp. 1054-1065.

[7] Nakanishi Y., Kusamoto H., Fukui S., et.al. Seedling Planting Tine of Seedling Planting Machine, Abstract of JP2007037444 (A).

[8] Zhao G.Z., Liu D.P. Design of seedling transplanting machine based on motion controller, International Conference on Computational Science and Engineering- ICCSE, 2015. pp. 556-560.

[9] Ceauşescu I., Legumicultura generală şi specială (General and special vegetable growing), Editura Didactică şi Pedagogică, Bucureşti (Didactic and Pedagogical Publishing House), Bucharest, 1980. 719 p. (In Romanian).

[10] Muraru-Ionel C. Maşini cu discuri flexibile pentru plantat răsaduri legumicole (Machines with flexible disks for planting vegetable seedlings), Editura Terra Nostra (Terra Nostra Publishing House), Iaşi, Romania, 2009.136 p. (In Romanian).

[11] Popescu V., Popescu A., Cultura legumelor din camp şi solaria (Vegetable crop in field and solariums), Editura MAST (MAST Publishing House), Bucharest, 2006. 256 p. (In Romanian).

[12] SR 13215:1994, Maşini de plantat răsaduri. Condiţii tehnice de calitate (Seedlings planting machines. Quality technical conditions), ASRO, Romania. (In Romanian).

[13] Tehnologie de înființare și valorificare superioară a materiei prime vegetale obținută din plante medicinal (Technology for the establishment and higher recovery of plant raw material obtained from medicinal plants), INMA Bucharest, Romania. [online][11.02.2020] Availabile at: https://inma.ro/wp-content/uploads/2019/02/materie_vegetala_plante_medicinale.pdf (In Romanian).

[14] AGROMAX Disc row planter [online][11.02.2020] Availabile at: https://www.youtube.com/watch?v=DmhlmGyA3dg. 